\title{
PITFALLS IN KENYA'S POSTCOLONIAL LANGUAGE POLICY: AMBIVALENCE IN CHOICE AND DEVELOPMENT
}

\author{
G Kitula King'ei
}

Kenyatta University, Kenya

Kenya's trifocal language policy is discussed with particular reference to the challenges and opportunities that African states have to grapple with in establishing a sound and workable language policy that will meet national and international needs. It is argued that fundamental questions have yet to be given serious attention. The focus of the discussion is on language use in education, but reference is also made to parliament and the media. A solution to the complex problems in Kenya cannot be found in the adoption of a national or official language. It is essential that particular roles and functions continue to be assigned to different languages, with appropriate provision made to equip citizens to use the various indigenous languages effectively for these purposes. The role or status enjoyed by any language should be complementary to those of the other languages and should also be determined by the prevailing socio-political needs and realities. This should make it possible to ensure that all Kenya's languages will enjoy desirable freedom to develop and expand.

In hierdie artikel word Kenia se taalbeleid met sy drie fokusse bespreek. Daar word in die besonder verwys na die uitdagings en geleenthede waarmee Afrikastate worstel in die proses om ' $n$ hegte en werkbare taalbeleid daar te stel wat aan nasionale en internasionale vereistes voldoen. Daar word beweer dat daar nog baie aandag aan fundamentele vrae gegee sal moet word. Die bespreking fokus op taalgebruik in die onderrigsituasie, maar daar word ook verwys na die parlement en die media. Een nasionale of amptelike taal bied nie 'n oplossing vir die komplekse probleme in Kenia nie, maar die toeken van spesifieke rolle en funksies behoort aan spesifieke tale wel. Gepaste toerusting behoort verskaf te word wat burgers in staat sal stel om die verskillende inheemse tale effektief vir hierdie rolle en funksies te kan gebruik. Die rol of status wat enige een van die tale geniet, behoort aanvullend te wees tot dié van die ander tale en behoort bepaal te word deur heersende sosio-politieke behoeftes en realiteite. Dit behoort oọ te verseker dat al die tale van Kenia die vryheid sal hê om te ontwikkel en uit te brei.

\section{INTRODUCTION}

Kenya is a multi-lingual country with over forty languages (Omondi, 1993). Most of these languages belong to the dominant Bantu group of languages though a number fall under the Nilotic and Cushitic groups. The orthographies of a number of these languages were developed just about six or so decades ago. In the case of the others, the writing systems are still being debated upon. This has meant that the role assigned to these languages in education and other aspects of national life has been rather limited, as is the body of literature available in them. Needless to say, these roles have been heavily influenced by, among other factors, 
the politics of the day as well as the attitudes of the speakers themselves. The foundations and policies laid down by the colonial authorities and the missionaries who played a key part in the provision of formal and vocational education in the country between 1980s and 1950s, remain crucial in modern language policy considerations.

Kenya has a kind of trifocal language policy that recognises the role of the vernaculars, Kiswahili and English in the national education system. The indigenous languages are given a limited role as the medium of instruction up to Primary Three, especially in the rural areas with one dominant language community. Kiswahili is the national language as weil as a compulsory subject taught and examined throughout Primary and Secondary cycles. It is also offered in most public universities. At the apex is English, the official language and medium of formal learning throughout the education system. English has a near co-status with Kiswahili, and the two languages remain locked in rivalry in the educational as well as other socio-economic domains in Kenya and East Africa as a whole. As is argued below, these two languages symbolise and often represent different and competing traditions and class interests.

\section{THE PROBLEM OUTLINED}

Recent research on language policies in Sub-Saharan Africa indicates that few of the 39 countries in the region have formulated and positively implemented their national language policies in their educational systems albeit in the lower levels (Macnab, 1989). Of these states, only Chad, Tanzania Ethiopia, Sudan, Somalia and Zimbabwe have successfully developed the use of selected local African languages as media of instruction at least, up to senior primary. Quite a number of the countries in the region do not have a declared language policy. Kenya lies between these two types of countries.

Two factors have been cited as affecting the use of African languages in formal education: the language situation obtaining in a given country and the country's colonial history. These two factors are largely responsible for the dilemma experienced by most post-colonial African states such as Kenya in their attempt to harmonise their declared national development goals and language policies. The common tendency, especially among the multi-lingual nations, has been to continue the use of former colonial policies and languages. Often the justification offered for this option is that it is politically more expedient to adopt such foreign languages over the local ones and thus help to diffuse socio-political tension or strife, which would have resulted on choosing one indigenous language over the rest.

This is what Fishman (1968) describes as the easy alternative taken by most developing countries. It is the argument of this article that, although this temporary option seems to work for the short-term, it is only a stop-gap measure which can not be relied upon to lead to the achievement of the declared or desired educational or developmental objectives. For instance, this kind of language policy does little to realise the ideal of empowering the indigenous languages with a view to having one of them replace the former colonial language in formal education as was the case to some extent, in India and the Philippines in the 1950s and 1960s. Such policies are, therefore, mainly ameliorative and quite often, cosmetic.

This article explores some of the challenges and opportunities that most typical African states, as exemplified by Kenya, have to grapple with in the difficult task of forging a sound and workable language policy for use in various sectors of national and international life, and 
especially in the educational sector. The article asserts that, as a young nation, Kenya seems to have largely glossed over the fundamental question raised by B.Ogot in his forward to the seminal work on Kenyan languages in Whitely (1974:ix). Reiterating that multi-lingualism is an escapable feature of African life, Ogot points out that sooner or later, each African state must come to terms with some or all of the following questions:

a) Is it affordable, practicable or even necessary to develop all the local indigenous languages equally?

b) What should be the role of foreign languages in education and nation - building?

c) Which of the indigenous languages should be adopted as the official language of the country?

d) What should be the place of indigenous languages in the education system?

e) When should the use of a second language be introduced in the education system?

It is, therefore, the interest of this article to describe historically the nature and evolution of Kenya's language policies and offer a critical evaluation of its implementation, exposing the ambivalent nature inherent in the various stages of the process.

\section{THE EVOLUTION OF KENYA'S LANGUAGE POLICY}

To gain a fuller picture of the nature and genesis of Kenya's national language policy making and implementation, it is necessary to take a diachronic view of both the colonial and postcolonial eras.

\section{Pre-Independence Period}

Colonial administrators as well as the missionaries realized the need to formulate a systematic language policy for Kenya, Uganda and Tanzania (then Tanganyika). For instance, as early as 1844 the development of the Kiswahili corpus had already informally began with the work of compiling the first dictionary of Kiswahili by the Rev. Dr Krapf followed the publication of a grammar handbook in 1870 (Chiraghdin and Mnyampala) 1977:54-55).

However it was in 1919 when the East African protectorate Education Inquiry Commission was set up to review the education system in the three British colonies (Mbaabu, 1991:20). In 1928, Directors of Education and Governors met at Dar es Salaam to deliberate on the future of African education in the region. As the first step toward the standardisation of Kiswahili to be used as a medium for African education, it was agreed to set up the East African Language Committee starting in 1930.

Generally speaking, at this time the educational authorities in Kenya were in agreement that the tri-focal language situation in education be maintained. In this arrangement, the vernaculars were to serve as the medium of instruction in African schools while English was introduced as the medium in the upper primary stages. In the urban centres the medium was Kiswahili up to Primary Three. The situation continued till around 1951 when it was decided to replace Kiswahili as the medium with English (Mbaabu, 1996:115-6). This new policy fitted well with the three-tier racial stratification of Kenyan society of the time: Europeans, Asians and Africans. Pupils from each of the three groups were taught in different mediums of instruction. Africans were taught either in Kiswahili or the vernaculars, while Asians were instructed in Gujarati, Hindi, Punjabi or Urdu and European schools used English. 
Since this policy privileged English over the other languages as the medium of formal education to the highest levels, Asian and African learners were placed at a clear disadvantage and often performed dismally in the national examinations. The next milestone in the evolution of Kenya's language policy came between 1957 and 1961 when the Department of Education launched a new programme using English medium to teach at all levels in all African and Asian schools. African schools experienced the worst problems in implementing this policy since they lacked well trained, adequate numbers of teachers, by comparison with their Asian and European counterparts. However, English medium classes increased steadily from 8 in 1962 to 1921 in 1965, signaling the growing sense among Africans of the importance of English as the medium of education as well as an avenue for upward socio-economic mobility.

\section{Post-Independence Era}

Since independence in 1963, many commissions of inquiry into the Kenya educational system as well as human resource development needs, have been set up. The effect on language policy of the ensuing reports has been far-reaching. In addition to these commissions, pronouncements by the ruling party, KANU and Developments Plans have also provided useful sources for language policy related information. The relevant views contained in these documents are briefly summarized below:

\section{The Ominde Report of 1965}

This famous commission was the first post-colonial education review in Kenya mandated to overhaul the colonial hang-over in the system. This famous commission did not wholly live up to that expectation. The recommendations of this Commission, with critical commentary on them, are as follows:

a) That English be adopted universally in the education system as the only viable medium of instruction.

b) That Kiswahili be introduced as a compulsory subject from Primary One.

The justification offered by the commission for elevating English and relegating vernaculars and Kiswahili to the background was often wanting. Here are a few examples:

(i) That English provides a better medium for learning languages and literacy than the vernaculars.

Does this assertion imply that African languages lacked the capacity to carry literacy, or that literacy imparted in the these languages would be inferior to that carried through English? The claim makes no linguistic sense at all.

(ii) That English would provide a more systematic and quicker development in all other subjects of study.

(iii) That the foundation laid in the first formative years of schooling would be more scientifically conceived and solidified if offered in English as opposed to the vernaculars.

(iv) That the transition form vernaculars to English medium was difficult and unnecessary. 
Statements (ii-iv) above are not only faulty but deliberately twisted to appear linguistically and educationally sound. The assertions seem to suggest that English is the only language that is sufficiently systematic and equipped to serve as a medium of teaching while the rest are not. This view is contrary to the linguistic principle which states that ideally, all human languages have the grammatical potential of serving all the communication needs within the social environment of the speech community (Langacker 1973:246-57). The recommendations by the Commission that Kiswahili be introduced as a subject from Primary One and a Department of Kiswahili be started to promote the language at the University of Nairobi were not implemented until 1985 and 1969 respectively.

\section{The Wamalwa Report of 1972}

This Committee was charged with the study of reviewing the Kenyan government's human resources training policies and with recommending any necessary changes. It made the following two important language-related recommendations:

a) That strong emphasis should be placed on programmes teaching foreign languages such French and German, in order to promote international trade, tourism and diplomacy.

b) That since most civil servants did not have a good command of Kiswahili, the national language, special in-service courses should be mounted at all training colleges for such staff.

Although the two recommendations were fully implemented, they did not have a crucial impact on the educational system. For instance, civil servants still prefer to address the public in English often through interpreters, due to the negative attitude towards Kiswahili and the vernaculars. On the other hand, despite the institution of degree courses in German and French at a number of colleges and universities, student enrolment in these programmes still remains low compared to those in Kiswahili and English. Perhaps this situation may be attributed to lack of career opportunities for graduates in these fields.

\section{The Gachathi Report of 1976}

This Commission made recommendations that seemed to contradict those of the Ominde Report before it. For instance, it recommended that:

(a) The medium of instruction in Primary One to Three be the dominant language of the school's catchment area.

Since the Ominde report had already stated that English was to be the universal medium for all schools, it is unclear why the new report regenerated on the earlier position. Again, the meaning of 'catchment area's language' no longer made a lot of sense since even the most remote rural areas had already experienced some degree of urbanization whereby Kenyans from different language groups worked and lived together. Trans-ethnic marriages also seemed to further complicate the presumed unifocal language situation. 
(b) Kiswahili be introduced as a subject only at Primary Three or whenever English was adopted as the medium of instruction.

This was a direct contradiction of the position suggested by the Ominde Commission. It would mean that different schools would start learning in English and learning Kiswahili as a subject at different stages. This statement further called for the examination of Kiswahili at Primary Seven, the then terminal stage for the primary cycle then.

(c) The introduction of English as the medium of instruction to take over from mother tongues as soon as possible.

This step which was again in contravention of recommendation above directing the use of the languages of the schools' catchment areas, actually dealt a death blow to the development of mother tongue education in Kenya.

The Mackay Report of 1981

The recommendations of this Commission have had far-reaching effects on Kenya's education system in general and also direct impact on language education itself. The specific recommendations were:

(a) That a Division incorporating the teaching of Kiswahili and other Kenyan languages be started in the Faculty of Social, Cultural and Development Studies in the new university that was to be started.

(b) That the teaching and examination of Kiswahili be expanded and intensified throughout the educational system up to university level.

Similar recommendations had already been made by the Wamalwa and Gachathi Reports referred to above but had been ignored until this time.

It is interesting to note that, unlike the earlier cases, all the recommendations of this commission were accepted and speedily implemented by the government.

\section{The Kamunge Report of 1988}

This report was prepared by a Commission named The Presidential Working Party on Education and Manpower Training for the Next Decade and Beyond. Surprisingly, the Commission did not make any language-related recommendations reflecting the low premium that the government attached to language planning and development issues. Although it made a recommendation for the establishment of a national council for creative and performing arts, the Party failed to recognise that language was actually the instrument of cultural and artistic expression.

\section{The Koech Report of 2000}

This is the most recent and also most controversial of independent Kenya's Education review reports. It made a number of observations and recommendations related to language education as follows: 


\section{Observations}

(a) Although many rural schools were teaching in the mother tongue there was an increasing tendency for many of them to insist on the English medium, just like their urban counterparts.

(b) It followed that 'the use of English at the pre-school and lower primary levels reduced the children's' mastery of their mother tongues' (p.276).

\section{Recommendations}

(a) Like the Ominde, Gachathi and other reports, the Koech report reiterated the need to stick to the language of the school's catchment area as the language for instruction. This ensured a smooth transition from home to institutionalized learning.

(b) It also called for the making of Kiswahili and English compulsory examination subjects in both primary and secondary schools and separation of the language and literature curriculars, a step that has sparked heated public debates on the merits and demerits of such a move.

(c) Materials for the teaching of mother tongues were to be produced although it was realised that the market for such materials would be severely limited.

(d) Sign language should be taught as a subject at the secondary school level $(9-11,2000)$.

(e) Like the Wamalwa team, Koech stressed the need to expand further university foreign language departments in order to cater for the trade and tourism industries.

\section{Other Sources of Language Policy}

\section{Ruling Party's Pronouncements}

Political speeches by the leader of the ruling party have also provided useful sources of language policy - related information. A good example is the 1969 wish to see Kiswahili being used as the official language in the National Assembly expressed by Mzee Jomo Kenyatta, Kenya's first President. This pronouncement was soon followed by detailed statements outlined by the party's Secretary General on how Kiswahili was going to be developed and promoted in such sectors as the civil service, lower law courts, and the provincial administration (Mbaabu 1996:132 - 134).

The steps included

(i) ordering Kenyans to speak Kiswahili

(ii) the establishment of Kiswahili learning centers nationally

(iii) Kiswahili competence to determine promotion or demotion in the civil service

(iv) Kiswahili proficiency tests for parliamentary candidates to qualify for election

However, these policy statements remained political rhetoric as none was ever implemented. 
Although the country has published a National Development plan regularly every 5 years since independence, only two of these documents have addressed the language problem. The 1979 - 83 and 1984 - 88 plans have briefly made statements about the government's intention with regard to language-related measures. In the first instance, an institute of Kiswahili Research was to be established at the University of Nairobi. In the other plan, the government announced that it was to mount campaigns to implement teach literacy and post-literacy adult education programmes in subjects such as family life and health, good citizenship and rural development. Again, as in the case of the ruling party's policies, none of these plans was actualised.

\section{THE PITFALLS AND AMBIVALENCES SUMMARISED}

The major weaknesses in the status planning and corpus development in Kenya's language policy consist in both those of commission and omission. It is what Anderson (1984:2) and Dubnick and Bardes (1983:11) refer to as, 'what governments choose to do or not to do or those actions that government officials take or avoid.'

Let us, for convenience sake, use the language-planning model constructed by Haungen (1966; 1983) in order to peg our criticism and evaluation of Kenya's language policy. This universal model sets out 4 stages for the planning process as follows:

(i) Norm selection

(ii) Norm codification (grammar, orthography and lexicon and standardization)

(iii) Functional implementation (promotion and spread of the use of the standardized variety or varieties throughout the media, education etc. and includes an evaluation of and acceptance of the chosen norm (s)

(iv) Functional elaboration (corpus planning e.g lexical modernization and expansion to equip the norm (s) scientifically and technologically).

\section{Evaluation}

(a) As far as stage (i) and (ii) above are concerned, Kenya's language policy has been satisfactory. However, the biggest problem here has been the attempt to codify all the over 40 norms (or languages). The experience up to date has been that only about 20 of these have been committed to writing by the Kenya Institute of Education.

(b) Contradictions and ambivalence have characterised the process of norm selection especially in education and parliament. For example, in 1974, section (53) of the constitution was amended to make Kiswahili the official language in the House, replacing English, but at the same time, to qualify for election to the National Assembly, one only needed to demonstrate proficiency in English.

In 1975, further amendment to the same section (53) was effected making English a coofficial language with Kiswahili. However, since other relevant sections of the Act were not amended, this policy left a situation where all bills, acts of parliament, financial legislation and proposed motions, announcement or contracts and house proceedings are all written in 
English. Kiswahili is only used for verbal debates from the floor of the House (Balustain and Rush, 1988: 30-31)

This situation continues to privilege English over Kiswahili, the national language, even in the National Assembly.

As pointed out above, the role assigned indigenous languages in education in Kenya has been limited from pre-school to Primary Three and then only in very few rural areas.

(c) Similarly, their use in the media (with an exception of Kiswahili) remains rather limited because the government's policy in this area is contradictory and unclear. For instance, although the state has licensed several local language or vernacular media radio stations, it has recently been waging political war against the same (Daily Nation, Sept. 1, 2000).

(d) Failure by the government to establish official language planning and development institutions has undermined the country's capacity to undertake functional elaboration activities mentioned in (iv) above. This has seriously jeopardized the development of the Kiswahili corpus, as well as that of the mother tongues.

Kenya seems to have over-concentrated on what Whitely (1969:116) refers to as 'the ideological aspects of policy developments to the exclusion of the technological ones'. As a result, the political pronouncements and statements are only aimed at short-term populist goals but are never followed by sustained efforts to develop the languages internally (117).

\section{CONCLUSION}

This article set out to outline the major sources of independent Kenya's language policy and to point out some of the glaring pitfalls in the process in as far as the planning and implementation are concerned. The focus of the discussion has been language use in education although other sectors such as parliament and media have been mentioned for illustrative purposes. The article has demonstrated that although Kenya is a typical example of the contemporary situation of language in Sub-Saharan Africa, she has her own unique characteristics. The following conclusions may be drawn:

(a) The complexity and sophistication of Kenya's situation can not be glossed over, ignored or overcome simply by the adoption of a national or official language this measure does not give rise to a unifocal society (Whitely 1969:114). It is therefore necessary to continue assigning different languages various roles and functions and, even more crucial, to equip these languages to effectively fulfill those roles and functions.

(b) Like most other African countries, Kenya seems to have fallen victim of the stereotypical dichotomy often drawn between the goals of nationalism (or national integration and the development of a multi-lingual and multi-cultural society. In this situation, multi-lingualism is viewed as an obstacle to nationalism and hence, it is used to justify the adoption of a foreign language, which is often, regarded as 'neutral' politically and socio-culturally (Polome and Haugen in Fishman, 1968:44). The overideologization of a multi-lingual society such as Kenya may, on one hand, magnify or even manufacture minor or non-existent linguistic differences. On the other hand, it 
may also include major differences thereby causing serious socio-political and even educational problems (Mazrui, 1998:9).

(c) There is need to realize that although the choice of a foreign language as official and educational language may, to a certain extent, minimize internal linguistic decisiveness, this is not a lasting solution:

(i) Foreign languages like English in Kenya are minority languages spoken by less than $20 \%$ of the population and only spoken as foreign languages (Mazrui, 1975). Therefore, although English remains the language of the power elite and determines social mobility, it is Kiswahili that promotes both horizontal and vertical integration (Mazrui, 1995).

(ii) Foreign languages can not replace indigenous languages as instruments of nation building. Therefore, the continued policy that makes these languages compete on a co-status with local national languages, e.g. Kiswahili, is not justifiable.

(iii) The claim that foreign languages are needed as official education media in postcolonial societies such as Kenya is not supported by empirical research in many European and South East Asian countries such as Korea, Hong Kong, Malaysia, Indonesia, Japan and China (Prah, 1998:4-5).

(iv) Although African languages in Kenya's education system have been assigned an extremely limited and and unimportant role, history has confirmed that these languages have a crucial role to play in the cultural lives of the people. Since the vernaculars cannot therefore be outlawed or wished away, the time has come to empower and modernise them so that they can assume a more central role in the formal and informal or non-formal education curricula.

(v) As far as Kiswahili is concerned, recent policies have fostered the rapid development of the language as a subject of study throughout the system of education. However, the failure by the government to set up legally empowered institutions for corpus development and planning is a glaring mistake. Hopefully, the newly adopted motion by Parliament calling for the establishment of a National Languages Council will lessen Kenya's dependence on corpus for Kiswahili developed in Tanzania.

Finally, it is important to stress that the role or status enjoyed by any language should be complementary to that of the other languages, and should also be determined by the prevailing socio-political needs and realities. This kind of policy will ensure that all Kenya's languages, the degree of political visibility of their communities notwithstanding, will enjoy desirable freedom to develop and expand.

\section{REFERENCES}

ANDERSON, J. 1984. Public policy making. New York: Holt Reinhart \& Winston.

BULASTEIN, A and RUSH, K. (Eds.) 1988. Constitutions of the countries of the world. Kenya 1980-1988. New York: Ocean Publications. 
CHIRANGHDIN, S and MNYAMPALA, M. 1977. Historia ya Kiswahili. Nairobi: Oxford University Press.

CONSTITUTION OF KEYNA 1983. Laws of Kenya. Nairobi: Government Printer.

DAILY NATION, Nairobi, 1 September 2000 p.1.

DUBRICK, MJ and BARDES, BA. 1983. Thinking about Public Policy. New York: John Wiley.

FISHMAN, JA, FERGUSON CA and DAS GUPTA, J (Eds). 1968. Language problems of developing nations. The Hague: Mouton.

GACHATHI, P. 1976. Report of the National Committee on Educational Objectives and Policies. Nairobi: Government Printer.

HAUGEN, E. 1983. The Implementation of Corpus planning: Theory and Practice. In Fishman J and Cobarrubias J, Progress in Language Planning. Berlin: Mouton.

KAMUNGE, J. 1988. Report of the Presidential Working Party on Education and Manpower. Nairobi: Government Printer.

KOECH, D. 2000. Report of the Commission of Inquiry. Nairobi: Government Press.

LANGACKER, R. 1973. Language and its structure. New York: Harcourt.

MACKAY. 1981. Second University in Kenya: Report of the Presidential Working Party. Nairobi: Government Printer.

MACNAB, C. 1996. Language policy and language practice. Stockholm: Institute of International Education. University of Stockholm.

MAZRUI, A. 1975. Political sociology of the English language: An African Perspective.

MAZRUI, A. 1995. Swahili State and Society. Nairobi E.A.E.P.

MAZRUI, A. 1998. The Power of Babel. Oxford: James Currey. National Development Plans.

MBAABU, I. 1991. Historia ya Usanifishaji wa Kiswahili. Nairobi: Longman Kenya.

MBAABU, I.1996. Language Policy in East Africa. Nairobi: E.AR.P

OGOT, B. 1974. Forward to Whitely, WH (Ed), Language in Kenya. Nairobi: Oxford University Press.

OMINDE, S. 1965. Commission of Inquiry. Nairobi: Government Printer 
PRAH, K. (Ed). 1998. Between distinction and extinction: Harmonization and standardization of African languages. Johannesburg: Witwatersrand University Press.

WAMALWA WN. 1971. Training Review Committee. Nairobi: Government Printer.

WHITELY, WH. 1969. The Rise of a national language. London: Methuen \& Co.

WHITELY, WH. 1971 (Ed.). Language use and social change. Nairobi: Oxford University Press.

WHITELY, WH. 1974. (Ed.). Languages in Kenya. Nairobi: Oxford University Press.

* This article was first presented as a paper at the CALSSA Conference: Applied Language Studies and Services into the Millennium. University of Cape Town, December 2000.

\section{Biographical note}

Professor Katula King'ei teaches in the Department of Kiswahili and Other African Languages at Kenyatta University, Kenya (P O Box 43844, Nairobi, Kenya)

(e-mail:avuku@ku.ac.ke). 